\title{
MODEL PEMBIASAAN KARAKTER KEDISIPLINAN MELALUI KEGIATAN EKSTRAKULIKULER PRAMUKA DI MI AL-MUHSIN YOGYAKARTA
}

\author{
Mizaniya $^{1} \&$ Muqowim $^{2}$ \\ UIN Sunan Kalijaga Yogyakarta \\ 19204080018@student.uin-suka.ac.id¹,muqowimk@gmail.com²
}

\begin{abstract}
This research is motivated by the current era of strengthening character education is an important thing to do considering the number of loss of character education values currently very alarming. One of the characters that must be possessed by students as an effort in social problems is the character of discipline. The formulation of the problem in this study is how to model the discipline of disciplinary character through scout extracurricular activities in MI AlMubsin Yogyakarta. The purpose of this study was to determine the model of disciplinary character habituation through scout extracurricular activities at MI Al-Mubsin Yogyakarta. This research method is a type of descriptive research with a qualitative approach. Research subjects include the headmaster of madrasas, teachers, scoutmaster, and students. This research was conducted at MI Al-Mubsin Yogyakarta. When thbis research was conducted around March-April 2020. Data collection techniques used were observation, interviews, and documentation. Data collection tools used are audio, video and photo recording. Check the validity of the data by triangulating data and sources. While the data analysis used is data reduction, data presentation and data verification. The results showed that there was a model for disciplining character through the scout extracurricular activities at MI Al-Mubsin Yogyakarta through rewards and punishments applied. There is a relationship between scout extracurricular activities and disciplinary character. Evidence of the success of the Boy Scouts extracurricular activities in building disciplinary character at MI Al-Mubsin Yogyakarta, namely five minutes before the ceremony the students are ready and gathered by wearing the full boy scout uniform, students in an orderly manner paying front group contributions, and students are willing to pay fines and money Scoutmaster also pays if he does not order too. This research can add knowledge, experience as well as insights on the disciplinary character refraction model through scout extracurricular activities so that it can improve and be considered for other researchers, as prospective educators to enter the world of education.
\end{abstract}

Keywords: Disciplinary, Model, Scout

Abstrak: Penelitian ini dilatarbelakangi oleh di era sekarang penguatan pendidikan karakter
merupakan hal yang penting untuk dilakukan mengingat banyaknya hilangnya nilai-nilai
pendidikan karakter saat ini sangat memprihatinkan. Salah satu karakter yang harus dimiliki
oleh peserta didik sebagai upaya dalam masalah sosial adalah karakter disiplin. Rumusan
masalah dalam penelitian ini adalah bagaimana model pembiasaan karakter kedisiplinan
melalui kegiatan ekstrakulikuler pramuka di MI Al-Muhsin Yogyakarta. Tujuan dari penelitian
ini adalah untuk mengetahui model pembiasaan karakter kedisiplinan melalui kegiatan
ekstrakulikuler pramuka di MI Al-Muhsin Yogyakarta. Metode penelitian ini ialah jenis
penelitian deskriptif dengan pendekatan kualitatif. Subjek penelitiannya meliputi kepala
madrasah, guru, pembina pramuka, dan peserta didik. Penelitian ini dilakukan di MI Al-

Fondatia : Jurnal Pendidikan Dasar

Volume 4, Nomor 2, September 2020; 205-221

https://ejournal.stitpn.ac.id/index.php/fondatia 
Muhsin Yogyakarta. Waktu penelitian ini dilaksanakan sekitar bulan Maret-April 2020. Teknik pengumpulan data yang digunakan adalah observasi, wawancara, dan dokumentasi. Alat pengumpul data yang digunakan yaitu rekaman audio, video, dan foto. Pemeriksaan keabsahan data dengan triangulasi data dan sumber. Sedangkan analisis data yang digunakan adalah reduksi data, penyajian data dan verifikasi data. Hasil Penelitian menunjukkan bahwa terdapat model pembiasaan karakter kedisiplinan melalui kegiatan ekstrakulikuler pramuka di MI Al-Muhsin Yogyakarta melalui reward dan punisment yang diterapkan. Adanya hubungan antara kegiatan ekstrakulikuler pramuka dengan karakter disiplin. Bukti keberhasilan kegiatan ekstrakulikuler pramuka dalam membangun karakter disiplin di MI Al-Muhsin Yogyakarta yaitu lima menit sebelum upacara peserta didik sudah bersiap dan berkumpul dengan mengenakan seragam pramuka lengkap, peserta didik dengan tertib membayar iuran gugus depan, dan peserta didik suka rela membayar uang denda serta pembina pramuka juga membayar jika tidak tertib juga. Penelitian ini dapat menambah pengetahuan, pengalaman serta wawasan tentang model pembiasan karakter kedisiplinan melalui kegiatan ekstrakulikuler pramuka sehingga dapat meningkatkan serta sebagai bahan pertimbangan bagi peneliti lain, sebagai calon pendidik untuk terjun ke dunia pendidikan.

Kata Kunci: Kedisiplinan, Model, Pramuka

\section{PENDAHULUAN}

Penguatan pendidikan karakter di era sekarang merupakan hal yang penting untuk dilakukan mengingat banyaknya hilangnya nilai-nilai pendidikan karakter saat ini sangat memprihatinkan. Alasan pentingnya penguatan nilai karakter disiplin di sekolah yaitu banyaknya terjadi perilaku peserta didik yang bertentangan dengan norma disiplin. Contohnya hal itu dibuktikan dengan datang kesekolah tidak tepat waktu, dari rumah berangkat tidak sampai di sekolah atau madrasah, bolos sekolah atau meninggalkan sekolah tanpa ijin, parkir tidak di tempat yang telah ditentukan, tidak memakai seragam sekolah sesuai dengan yang tercantum dalam tata tertib sekolah atau madrasah, berbicara kotor, merokok, membuang sampah sembarangan, mencorat-coret dinding atau prasarana sekolah, mengumpulkan tugas tidak tepat waktu, tidak memperhatikan guru saat menjelaskan, tidak mengikuti kegiatan ekstrakurikuler, mengkonsumsi minuman beralkohol, berpacaran yang melanggar norma, tidak mengikuti kegiatan keagamaan, kurangnya perilaku kejujuran dalam berbicara, bullying, tidak memakai sepatu berwarna hitam, perkelahian, menyontek, pemalakan, pencurian, kedisiplinan peserta didik dalam mentaati tata tertib sekolah, ikut geng motor, duduk atau berjalan dengan seenaknya menginjak tanaman yang jelas-jelas sudah dipasang tulisan “dilarang menginjak tanaman”, dan perilaku negative peserta didik lainya (Hartini, 2017: 39). Pendidikan hendaknya juga 
membentuk karakter peserta didik, tidak hanya menciptakan manusia yang cerdas (Nuriyatun, 2016: 2). Oleh karena itu, penguatan pendidikan karakter perlu dilaksanakan sedini mungkin dimulai dari lingkungan keluarga, sekolah, dan meluas ke dalam lingkungan masyarakat. Salah satu karakter yang harus dimiliki oleh peserta didik sebagai upaya dalam masalah sosial adalah karakter disiplin. Pada peserta didik karakter disiplin sangat penting untuk diajarkan dan diterapkan guna membangun jati diri bangsa yang berkarakter (Utari, 2016: vii).

Pendidikan kepramukaan merupakan proses pendidikan luar lingkungan sekolah dan di luar keluarga dalam bentuk kegiatan yang menarik, menyenangkan, sehat, teratur, disiplin, terarah, dan praktis yang dilakukan di alam terbuka dengan Prinsip Dasar Kepramukaan dan Metode Kepramukaan (PDK dan MK) yang sasaran akhirnya yaitu pembentukan karakter anak didik yang baik (Risky, 2007: 11). Kegiatan Pramuka ini akan mampu membangun kecerdasan peserta didik pada ranah afeksi (sikap dan perilaku), sehingga peserta didik akan mampu mengembangkan karakternya secara positif. Kebijakan Pramuka yang dijadikan sebagai ekstrakulikuler wajib di sekolah menjadi faktor penting dalam mewujudkan pendidikan karakter. Sebagaimana kita ketahui bersama bahwa proses pembelajaran di kelas lebih dominan pada pengembangan otak kiri (IQ: Intelectual Quotient), sementara pengembangan otak kanan (EQ: Emotional Quotient) seringkali mendapatkan porsi yang sangat sedikit. Pramuka adalah wahana pengembangan emosional otak kanan, di mana peserta didik dilatih untuk berinteraksi, berkomunikasi, kreatif, dan berafiliasi dengan teman-teman lainnya (Mustagfiroh, 2020: 1). Kegiatan ekstrakurikuler kepramukaan sangat menonjol yaitu dalam pendidikan karakter disiplinnya, karena peserta didik sangat menginginkan kebebasan seperti halnya bermain dan lainnya (Laela, 2017: 4).

Ekstrakurikuler adalah kegiatan yang dilakukan peserta didik di sekolah atau universitas, di luar jam belajar kurikulum standar. Kegiatan-kegiatan ini ada pada setiap jenjang pendidikan dari dasar sekolah sampai universitas. Kegiatan ekstrakurikuler ditujukan agar peserta didik dapat mengembangkan kepribadian, bakat, dan kemampuannya di berbagai bidang di luar bidang akademik. Kesadaran menegakkan disiplin dapat dilatih dengan kegiatan-kegiatan positif yang diadakan sekolah melalui ekstrakurikuler. Salah satunya adalah kegiatan pramuka. Dari kegiatan 
pramuka inilah peserta didik akan dibiasakan untuk berlaku disiplin di setiap kegiatan yang diadakan. Antara kegiatan pramuka dan kedisiplinan memiliki hubungan yang erat (Wadlifah, 2013: 2). Kegiatan ekstrakurikuler kepramukaan dimaksudkan untuk mempersiapkan generasi muda sebagai calon pemimpin bangsa agar memiliki watak, kepribadian dan akhlaq mulia, serta keterampilan hidup prima (Mulyasa, 2011: 26-27). Kegiatan ekstrakulikuler pramuka jauh lebih menyenangkan atau menarik ketimbang pembelajaran di kelas yang cenderung kaku dan membosankan.

Keunikan dari kegiatan ekstrakulikuler pramuka di MI Al-Muhsin Yogyakarta yaitu adanya kontrak belajar yang sudah disepakati oleh pembina dan peserta didik, contohnya menerapkan reward dan punishment. Contohnya apabila peserta didik melanggar peraturan yang sudah disepakati maka mereka akan siap mendapat hukuman, seperti peserta didik tidak berpakaian lengkap, terlambat hadir dalam kegiatan pramuka maka mereka akan kena denda sebesar lima ribu rupiah setiap pelanggar yang dilakukan dan begitupun sebaliknya apabila pembina melanggar maka pembina juga akan mendapatkan hukuman sama seperti peserta didik akan tetapi hukuman yang didapat pembina dua kali lipat dari peserta didik. Dimana uang denda yang terkumpul dimasukkan ke dalam uang kas, dimana uang kas ini bisa dipergunakan untuk kegiatan ekstrakulikuler pramuka yang mebutuhkan biaya lebih dalam kegiatannya. Tentunya adanya punishment atau sistem denda yang dibuat sudah dikomunikasikan antara pembina dengan pihak sekolah dan sudah diberitahukan kepada wali murid atau orang tua peserta didik bahwasanya anak-anak tidak tertib akan kena denda jadi daripada kena denda lebih baik anak-anak tertib. Adanya beberapa dari guru-guru yang mengajar mensupport dalam kegiatan ekstrakulikuler pramuka. Pandangan dari guru-guru yang mengajar di sana merasa terkesima untuk apabila peserta didik disuruh untuk kumpul dalam konteksnya bukan pramuka mereka sulit atau susah untuk baris akan tetapi apabila peserta didik memakai seragam pakaian lengkap pramuka dan sudah ada pembina pramuka membuat peserta didik cepat untuk baris dan tertib dalam kegiatan ekstrakulikuler pramuka.

Alasan peneliti memilih MI Al-Muhsin Yogyakarta sebagai tempat penelitian tersebut sampai saat ini masih aktif melaksanakan kegiatan ekstrakurikuler pramuka, peserta didiknya relatif banyak, pembina pramuka dan peserta didik di MI Al-Muhsin 
Yogyakarta bumble, lokasi tempat penelitian dekat dengan rumah peneliti, dalam kegiatan ekstrakulikuler pramuka namun adik-adiknya susah diatur serta jalan dan lari ke sana kemari. Maka peneliti tertarik untuk mengangkat penelitian dengan judul "Model Pembiasaan Karakter Kedisiplinan Melalui Kegiatan Ekstrakulikuler Pramuka Di MI Al-Mubsin Yogyakarta”.

\section{METODE PENELITIAN}

Metode penelitian ini ialah jenis penelitian deskriptif dengan pendekatan kualitatif. Penelitian kualitatif ialah penelitian yang dimaksudkan untuk memahami fenomena tentang apa yang di alami oleh subjek penelitian misalnya perilaku, motivasi, presepsi, tindakan dan sebagainya (Meolong, 2005: 6). Subjek penelitiannya meliputi kepala madrasah, guru, pembina pramuka, dan peserta didik. Penelitian ini dilakukan di MI Al-Muhsin Yogyakarta. Waktu penelitian ini dilaksanakan sekitar bulan Maret-April 2020. Teknik pengumpulan data yang digunakan adalah observasi, wawancara, dan dokumentasi. Alat pengumpul data yang digunakan yaitu rekaman audio, video, dan foto. Pemeriksaan keabsahan data dengan triangulasi data dan sumber. Sedangkan analisis data yang digunakan adalah reduksi data, penyajian data dan verifikasi data.

\section{HASIL DAN PEMBAHASAN}

Kata Pramuka adalah singkatan dari PRA PRA : Praja (masyarakat), MU : Muda, KA : Karana (kata asli dalam bahasa Sanskrit "KRNA" yang berarti kreatif dan berkarya). Dengan demikian Pramuka bermakna anak muda yang kreatif (Barat, 1998: 134). Pramuka merupakan sebutan bagi anggota kegiatan pramuka, yang berusia antara 7 sampai dengan 25 tahun, dan berkedudukan sebagai peserta didik, yaitu sebagai pramuka siaga, pramuka penggalang, pembina penegak, dan pramuka pandega (Suryani, 2017: 10). Kepramukaan merupakan suatu sistem pendidikan kepanduan yang disesuaikan dengan keadaan, kepentingan, dan perkembangan bangsa serta masyarakat Indonesia (Yusup, 2014: 45). Kepramukaan adalah suatu wadah pendidikan anak yang dilaksanakan di luar jam pelajaran sekolah. Tujuannya adalah membentuk kepribadian anak. Adapun pengembangannnya diarahkan pada 
peningkatan ketahanan nasional dan pembinaan daya tahan masyarakat (Juwantara, 2009: 161). Pendidikan Kepramukaan adalah proses pembentukan kepribadian, kecakapan hidup, dan akhlak mulia pramuka melalui pengayatan dan pengamalan nilai-nilai kepramukaan (Nuh, 2014: 2). Pendidikan kepramukaan dilaksanakan sebagai kegiatan ekstrakulikuler wajib pada pendidikan dasar dan menengah. Kegiatan ekstrakulikuler wajib merupakan kegiatan ekstrakulikuler yang harus diikuti oleh seluruh peserta didik (Nuh, 2014: 3).

Bila ditelusuri asal karakter berasal dari bahasa Latin "kharakter", "kharassein", "kharax", Yunani character, dari charassein yang berarti membuat tajam, membuat dalam. Dalam Kamus Poerwadarminta, karakter diartikan sebagai tabiat, watak, sifatsifat kejiwaan, akhlak atau budi pekerti yang membedakan seseorang dengan yang lain. Ciri pribadi yang meliputi hal-hal seperti perilaku, kebiasaan, kemampuan, kecendrungan, potensi, nilai-nilai dan pola-pola pemikiran (Majid, 2011: 11). Di dalam Kamus Bahasa Indonesia, karakter mengandung makna sifat-sifat kejiwaan, akhlak, atau budi pekerti yang membedakan seseorang dari yang lain. Dari pengertian tersebut dapat artinya karakter merupakan cerminan dari kepribadian diri seseorang yang meliputi mental, sikap, dan perilaku (Ismayaningrum, 2016: 30). Karakter yang baik yaitu terdiri dari mengetahui hal yang baik, menginginkan hal yang baik, dan melakukan hal yang baik lalu membiasakannya. Ketiga hal ini diperlukan untuk mengarahkan suatu kehidupan dan membentuk kedewasaan moral (Lickona, 2015: 48).

Disiplin berasal dari kata Disciple yakni seseorang yang belajar atau suka rela mengikuti seorang pemimpin. seiring dengan perkembangan zaman, kata disipin mengalami perubahan menjadi discipline yang artiya kepatuhan atau yang menyangkut dengan tata tertib (Hurlock, 1978: 42). Menurut bahasa Indonesia disiplin adalah tata tertib (di sekolah, kemiliteran, dan sebagainya), ketaatan (kepatuhan) kepada peraturan tata tertib dan sebagainya (Bahasa, 1989: 208). Disiplin tumbuh dari kebutuhan menjaga keseimbangan antara kecendrungan dan keinginan individu untuk berbuat agar memperoleh sesuatu, dengan pembatasan atau peraturan yang diperlukan oleh lingkungan terhadap dirinya (Conny, 2008: 27). Disiplin adalah tindakan yang menunjukkan perilaku tertib dan patuh pada berbagai ketentuan dan 
peraturan (Mustari, 2014: 42). Seseorang siswa dapat di katakan berprilaku disiplin jika sudah memenuhi indikator disiplin sebagai berikut datang ke sekolah tepat waktu, berpakaian rapi, memelihara fasilitas umum, melestarikan lingkungan, menjaga nama baik sekolah dan kebiasaan tertib (Zuriah, 2007: 255).

MI Al-Muhsin merupakan salah satu sekolah swasta yang berada di Yogyakarta dengan terakreditasi A. MI Al-Muhsin beralamat di jalan Parangtritis km 3,5 Krapyak Wetan Panggungharjo Sewon bantul Yogyakarta 55188 Telp. 02749317829 Hp. 08122700976 - 085865243792 . MI Al Muhsin merupakan lembaga pendidikan formal di bawah naungan Yayasan Aji Mahasiswa Al Muhsin binaan KH Muhadi Zainudin Lc. Lembaga ini berdiri sejak tahun 2010 dengan NPSN 60714034 serta Luas tanah sebesar $2 \mathrm{~m} 2$. MI Al-Muhsin mempunyai salah satu ekstrakulikuler pramuka. Ekstrakulikuler Pramuka di MI Al-Muhsin berdiri sejak 2014 sampai sekarang ini. Kegiatan ekstrakulikuler pramuka di MI Al-Muhsin setiap hari Rabu pukul 12.30 14.00 wib. Ekstrakulikuler pramuka terbagai menjadi dua bagian yaitu pramuka siaga dan pramuka penggalang. Pramuka siaga dikhususkan untuk kelas III-IV sedangkan pramuka penggalang dikhususkan untuk kelas V-VI. Sedangkan untuk pembina ekstrakulikuler pramuka di MI Al-Muhsin ada lima orang dimana pembina pramuka terbagi menjadi dua, pertama untuk tiga orang mengajar pramuka siaga dan kedua untuk dua orang mengajar pramuka penggalang.

Tenaga pembina pramuka yang ada di MI Al-Muhsin Yogyakarta didatangkan dari UKM Pramuka UIN Sunan Kalijaga Yogyakarta atau rekan anggota aktif Pramuka. Proses menjadi pembina pramuka di MI Al-Muhsin Yogyakarta yaitu Pertama, ada ketertarikan belajar mengajar Pramuka. Sekalipun tak punya trackrecord mengajar Pramuka nanti akan dibantu tips dan trik mengajar. Di tahap awal calon pembina akan menjadi asisten pembina: mengamati dan mempelajari bagaimana menjadi pembina. Tahap kedua nanti mulai diberi kesempatan mengajar. Kemudian jika ada kursus pembina diusahakan diikutsertakan. Menjadi sosok pembina pramuka yang baik ialah yang penting selalu patuh pada Tri Satya dan mengamalkan Dada Darma serta memberikan contoh real / nyata kepada peserta didiknya.

Dari hasil wawancara peneliti dengan dua orang pembina pramuka penggalang di MI Al-Muhsin yaitu Alfian Huda, S.Pd dan Rohmati Wahyu Tjadmijoko, mereka berdua 
menyatakan bahwa kegiatan pramuka yang ada di MI Al-Muhsin ini merupakan ekstrakulikuler wajib yang di ikuti oleh seluruh peserta didik khususnya kelas III -VI di MI Al-Muhsin Yogyakarta akan tetapi tidak semua peserta didik menyukainya. Menurut Alfian Huda, S.Pd bahwa integrasi adalah keterkaitan satu sama lain atau berkesinambungan dengan yang lain sedangkan menurut Rohmati Wahyu Tjadmijoko bahwa integrasi adalah adanya hubungan timbal balik dengan sinkron berjalan berbarengan.

Kurikulum ekstrakulikuler pramuka mengacu pada SKU (syarat kecakapan umum) dikembangkan oleh masing-masing pembina terutama pramuka siaga dimana dituntut lebih kreatif dalam belajar-mengajarnya, kalau dari MI-nya disisipkan muatan-muatan islaminya contohnya sebelum latihan adanya upacara, berdo'a bersama tetapi yang ditonjolkan ke materi kepramukaan itu sendiri. Bahan \& sumber ajar dalam ekstrakulikuler pramuka yang mendukung belajar dari internet, pengembangan dari pembina, sharing dengan teman, dan dari pengalaman masing-masing pembina. Media pembelajaran dalam ekstrakulikuler berupa media cetak dan tergantung dari materi yang akan dipelajari atau yang sudah direncanakan sesuai jadwal yang telah ditetapkan. Kegiatan ekstrakulikuler pramuka belajarnya bisa di dalam kelas atau diluar kelas. Ekstrakulikuler pramuka disini lebih menekankan skill / praktek dan tidak lepas dari patokan SKU. Kegiatan ekstrakulikuler pramuka contohnya materi pionerring dimana peserta didik membawa tali dan tongkat, materi penjernihan air, praktek memasak, atau survival/bertahan hidup diluar walaupun survival kegiatan yang tidak disenangin tentunya pembina memberikan stimulus dan arahan terlebih dahulu kepada peserta didik sebelum melakukan kegiatan ekstrakulikuler pramuka. Kegiatan pramuka yang penting peserta didik menyukai atau senang terlebih dahulu dengan pramuka, prinsipnya belajar sambil melakukan.

Implementasi ekstrakulikuler pramuka tergantung akan konteksnya, dimana pada pramuka adanya sistem among, pada pramuka sekolah dasar lebih mengedepankan Ing Agarsa Sung Tulada (didepan seorang pendidik harus memberi teladan atau contoh tindakan yang baik) sehingga pembina pramuka memberikan contoh atau tindakan terlebih dahulu lalu baru diikuti peserta didiknya. Faktor pendukung dalam kegiatan ekstrakulikuler pramuka yaitu sekolah, peserta didik, dan orang tua peserta 
didik. Faktor penghambat dalam kegiatan ekstrakulikuler pramuka yaitu fasilitas dari sekolah, contohnya lokasi tempat kegiatan ekstrakulikuler pramuka sedang dibangun jadi melakukan sulit untuk kegiatannya, kegiatan pramuka ekstrakulikuler pramuka pada waktu siang hari dimana latihan pada waktu terik matahari yang panas sehingga membuat peserta didik kurang antusias melakukan kegiatannya.

Cara mengajar kegiatan ekstrakulikuler pramuka santai dikarenakan peserta didiknya enak diajak komunikasi. Pada pramuka siaga dimana pembina pramuka harus memberikan citra yang asyik kepada peserta didik sehingga bisa mengambil hati dari mereka dikarenakan pada usia mereka masih bisa akan ikut dari contoh yang diberikan pembina pramuka dan lebih banyak bermain dalam belajarnya. Pada pramuka penggalang peserta didiknya sudah bisa diajak untuk berpikir atau bertukar peran dengan baik dan benar, contohnya ketika mereka melakukan kesalahan maka mereka akan tahu akan resiko yang akan di dapat, contoh lainnya ketika ada pembina yang sedang menjelaskan didepan dan peserta didik tidak memperhatikan sehingga yang tidak memperhatikan diminta untuk menjadi pembina didepan teman-teman lain dan tidak diperhatikan oleh temannya sehingga membuat mereka mengerti berada diposisi jadi pembina. Cara menarik minat peserta didik untuk mengikuti kegiatan ekstrakulikuler pramuka yaitu dengan cara saat pembelajaran diselipi ice breaking dan games.

Keunikan dari kegiatan ekstrakulikuler pramuka yaitu adanya kontrak belajar yang sudah disepakati oleh pembina dan peserta didik, contohnya menerapkan reward dan punishment. Contohnya apabila peserta didik melanggar peraturan yang sudah disepakati maka mereka akan siap mendapat hukuman, seperti peserta didik tidak berpakaian lengkap, terlambat hadir dalam kegiatan pramuka maka mereka akan kena denda sebesar lima ribu rupiah setiap pelanggar yang dilakukan dan begitupun sebaliknya apabila pembina melanggar maka pembina juga akan mendapatkan hukuman sama seperti peserta didik akan tetapi hukuman yang didapat pembina dua kali lipat dari peserta didik. Dimana uang denda yang terkumpul dimasukkan ke dalam uang kas, dimana uang kas ini bisa dipergunakan untuk kegiatan ekstrakulikuler pramuka yang mebutuhkan biaya lebih dalam kegiatannya. Tentunya adanya punishment atau sistem denda yang dibuat sudah dikomunikasikan antara pembina 
dengan pihak sekolah dan sudah diberitahukan kepada wali murid atau orang tua peserta didik bahwasanya anak-naak tidak tertib akan kena denda jadi daripada kena denda lebih baik anak-anak tertib. Adanya beberapa dari guru-guru yang mengajar mensupport dalam kegiatan ekstrakulikuler pramuka. Pandangan dari guru-guru yang mengajar di sana merasa terkesima untuk apabila peserta didik disuruh untuk kumpul dalam konteksnya bukan pramuka mereka sulit atau susah untuk baris akan tetapi apabila peserta didik memakai seragam pakaian lengkap pramuka dan sudah ada pembina pramuka membuat peserta didik cepat untuk baris dan tertib dalam kegiatan ekstrakulikuler pramuka.

Penilaian ekstrakulikuler pramuka ada tiga macam yaitu penilaian sikap, penilaian tugas, dan penilaian kehadiran. Dari ketiga macam penilaian yang sulit ialah penilaian sikap dikarenakan harus menghafal setiap nama-nama peserta didik sedangkan disetiap kelas peserta didik lebih dari dua puluh lima orang peserta didik. Biasanya pembina pramuka mempunyai buku harian yang berisi catatan harian tentang terkait kegiatan latihan pramuka rutin setiap kegiatannya, isi dari catatan harian contohnya adanya kejadian pelantikan, peserta didik yang berkelahi, kalau ada kumpul tugas, kalau ada praktek, peserta didik yang tidak lengkap atribut, peserta didik yang terlambat, dan sebagainya. Dalam tiga macam penilaian ekstrakulikuler pramuka diakumulasikan dengan merata.

Perbedaan antara peserta didik yang mengikuti kegiatan ekstrakulikuler pramuka dengan yang tidak yaitu Pertama, skill dari peserta didik yang mengikuti kegiatan ekstrakulikuler pramuka tentunya lebih terampil dari pada peserta didik yang tidak mengikuti kegiatan tersebut. Kedua, Peserta didik yang mengikuti kegiatan ekstrakurikuler pramuka tentunya orangnya lebih fleksibel, humble, mudah bergaul dengan siapapun, dan dapat menyesuaikan dengan lingkungan yang baru ketimbang peserta didik yang tidak mengikuti kegiatan tersebut. Ditingkat SD/MI kegiatan ekstrakulikuler pramuka diwajibkan.

Kekurangan dalam kegiatan ekstrakulikuler pramuka yaitu peserta didik sudah mengenal tentang pacaran di usianya padahal mereka masih terlalu kecil mungkin karena masa pubertas akan tetapi mereka membuat pembicaraan yang kurang baik dengan orang lain, anak-anak senang bermain dikarenakan masa perkembangan dan 
pertumbuhan mereka, ada peserta didik yang ribut/ ramai atau tidak mau baris akan tetapi mereka sudah tahu konsekuensinya apabila melanggar tata tertib dan sudah dibicarakan pada kontrak belajar. Kesulitan dalam kegiatan ekstrakulikuer pramuka yaitu pembina tidak bisa memaksa kehendak terhadap peserta didik dikarenakan adanya keterbatasan waktu kegiatan pramuka dimana kegiatan pramuka hanya satu jam setengah dalam pertemuan dan bertemu hanya seminggu sekali dalam kegiatan pramuka.

Solusi atau evaluasi dalam kegiatan ekstrakulikuer pramuka yaitu pada alokasi waktu kegiatan pada siang hari dimana sulit untuk mencari tempat belajar yang rindang atau teduh bagi peserta didik ketika belajar di luar lingkungan kelas selain itu untuk peserta didiknya sendiri lebih baik ketimbangan sekolah lainnya. Adanya aturan dalam kontrak belajar apabila ada peserta didik atau pembina yang melanggar aturan maka akan dikenakan sanksi yang telah dibuat secara bersama sedangkan untuk peserta didik yang tertib adanya apresiasi dengan diberikan reward. Apabila ada yang ribut di dalam kegiatan pramuka maka mereka akan diberikan tugas sendiri dan mereka akan pulang paling terakhir lalu akan ditanya dengan pembina.

Adanya nilai karakter ke peserta didik dalam kegiatan ekstrakulikuler pramuka di MI Al-Muhsin yaitu leadership, disiplin, tanggung jawab, rajin beribadah, patuh pada aturan yang berlaku, sosial \& empati yang tinggi. Contohnya nilai karakter leadership yaitu nilai kepemimpinan dari ketua regu harus tumbuh dikarenakan ketua regu adalah panutan regu untuk anggota kelompoknya. contoh nilai karakter tangung jawab yaitu ketika ada salah satu peserta didik yang melakukan pelanggaran maka mereka akan siap adanya konsekuensi hukuman bagi peserta didik atau pembinanya mereka siap akan dihukum. Contohnya nilai karakter disiplin yaitu apabila ada suara pluit maka peserta didik langsung baris dilapangan. Contohnya nilai karakter tawaduk yaitu apabila kegiatan sudah selesaai maka peserta didik disuruh untul salaman ke yang lebih tua satu persatu membentuk barisan. Contohnya nilai karakter rajin beribadah yaitu apabila sebelum melakukan kegiatan pramuka peserta didik disuruh untuk solat zuhur terlebih dahulu sebelum melakukan kegiatan ekstrakulikuler pramuka. 
Adanya hubungan antara kegiatan ekstrakulikuler pramuka dengan karakter disiplin. Pembangunan karakter kedisiplinan terhadap peserta didik di MI Al-Muhsin Yogyakarta sangat penting, dikarenakan dengan sikap disiplin peserta didik secara tidak langsung mudah dikondisikan sehingga akan mendukung suasana pembelajaran yang tertib tidak gaduh atau rami sendiri. Sehingga materi yang disampaikan dapat diterima dengan baik oleh peserta didik. Kegiatan yang mendukung pembangunan karakter disiplin terhadap peserta didik dalam kegiatan ekstrakulikuler pramuka di MI Al-Muhsin Yogyakarta yaitu kegiatan baris berbaris, upacara latihan, dan ketertiban seragam Pramuka. Proses penanaman karakter disiplin dalam kegiatan ekstrakulikuler pramuka di MI Al-Muhsin Yogyakarta yaitu pembina pramuka mencontohkan dahulu gimana ketertibannya. Adanya kontrak belajar. Jika peserta didik tidak menepati kena denda. Jika pembina pramuka tidak menepati denda dua kali lipat peserta didik.

Kendala seorang pembina pramuka dalam membina peserta didik yaitu minimnya fasilitas kegiatan berupa lokasi kegiatan sehingga kegiatan kurang kondusif. Dalam pelaksanaan kegiatan ekstrakulikuler pramuka di MI Al-Muhsin Yogyakarta yang di evaluasi dari segi fasilitas penunjang, semisal lokasi latihan karena jam latihan saat siang sehingga lokasi sangat terik. Hal ini berpengaruh terhadap minat peserta didik saat mengikuti kegiatan. Kemudian komunikasi antara guru dengan pembina perlu ditekankan melalui musyawarah rutin gugusdepan agar tercipta komunikasi yang baik antara sekolah dan pembina.

Bukti keberhasilan kegiatan ekstrakulikuler pramuka dalam membangun karakter disiplin di MI Al-Muhsin Yogyakarta yaitu lima menit sebelum upacara peserta didik sudah bersiap dan berkumpul dengan mengenakan seragam pramuka lengkap, peserta didik dengan tertib membayar iuran gugus depan, dan peserta didik suka rela membayar uang denda serta pembina pramuka juga membayar jika tidak tertib juga.

Faktor pendukung dalam menerapkan karakter disiplin pada kegiatan ekstrakulikuler pramuka di MI Al-Muhsin Yogyakarta yaitu Mungkin karena adanya hukuman atau denda sehingga anak-anak berusaha menghindari. Namun untuk mengindari kesan anak-anak terkekang dengan hukuman. Peserta didik yang tertib kita beri reward sehingga anak-anak jika harus memilih antara mengejar reward atau dihukum lebih 
baik mengejar reward. Selain itu peserta didik tidak sungkan ketika mengingatkan guru atau pembina jika tidak disiplin.

Kesulitan dalam menerapkan karakter disiplin pada kegiatan ekstrakulikuler pramuka di MI Al-Muhsin Yogyakarta yakni dikarena beberapa peserta didik adalah santri pondok jika diterapkan hukuman denda berupa uang, anak-anak agak susah. Solusi \& evaluasi yang dilakukan pembina untuk mendukung karakter disiplin pada kegiatan ekstrakulikuler pramuka di MI Al-Muhsin Yogyakarta yaitu solusinya dengan komunikasi antara sekolah-pembina-wali lebih ditingkatkan. Kemarin terkait aturan denda dan iuran sudah disampaikan via surat sehingga sejak awal sudah ditekankan kalo ada kebijakan pembina demikian sedangkan untuk evaluasi yakni karena waktu latihan setelah duhur sehingga kadang pembina sering terlambat karena melaksanakan duhur dulu sehingga ketika ada kegiatan yang sifatnya membutuhkan persiapan lebih sebelum pelajaran jadi agak susah.

Perubahan atau pengaruh dari karakter disiplin terhadap peserta didik dalam kegiatan ekstrakulikuler pramuka di MI Al-Muhsin Yogyakarta yaitu anak-anak terpacu untuk tertib, sehingga ketika guru atau pembina tidak disiplin mereka pun berani mengingatkan. Untuk kedepan yang pembina pramuka harapkan dari kegiatan ekstrakulikuler pramuka yang ada di MI Al-Muhsin Yogyakarta yaitu Kenaikan fee pembina dikarena beberapa pembina memang sedang mengikuti kursus pembina tingkat lanjut dan harapan ke depan guru pun diwajibkan memakai seragam pramuka pada hari tertentu agar anak-anak pun tidak sungkan mengenakan baju pramuka.

Kegiatan khusus pada akhir semester atau tahunnya dalam pelaksanaan kegiatan ekstrakulikuler pramuka di MI Al-Muhsin Yogyakarta yaitu kemah, fun games, persami, masak bareng, dan bakar bakaran. Upaya anda sebagai pembina pramuka untuk menciptakan inovasi dalam kegiatan ekstrakulikuler pramuka di MI Al-Muhsin Yogyakarta yaitu sering sharing dengan teman pembina, evaluasi dan konsultasi dengan pelatih pembina di kwarcab. Upaya yang dilakukan kakak pembina untuk mengadakan kegiatan ekstrakulikuler pramuka sebagai tempat belajar sambil bermain yaitu mengadakan kegiatan pramuka dengan sekolah lain misal adanya kemah bareng. Program kegiatan ekstrakulikuler pramuka di jalankan sesuai program sekolah sudah sesuai dikarena progam pembelajaran juga diawal tahun pelajaran juga sudah 
disampaikan sekolah. Dari pembina pramuka rutin melaksanakan evaluasi dalam kegiatan ektrakulikuler pramuka yang sudah berlangsung di MI Al-Muhsin Yogyakarta, baik evaluasi pembelajaran maupun evaluasi kemampuan peserta didik. Kemudian dilaporkan ke pihak sekolah utk ditindak lanjuti. Hanya saja karena kegiatan ektrakulikuler pramuka cenderung dipandang hanya sebagai ekstrakulikuler kadang masukan dan evaluasi progam pramuka tidak ditanggapi maksimal oleh sekolah.

Manfaat dan tujuan sekolah mengadakan ekstrakulikuler pramuka yakni Pertama, membentuk kemampuan peserta didik yang cakap dalam berbagai kecakapan hidup. Kedua, membentuk kepribadian yang disiplin dan bertanggung jawab serta kepemimpinan. Ketiga, menumbuhkan semangat nasionalisme.

\section{KESIMPULAN}

Berdasarkan hasil penelitian yang telah dilakukan oleh peneliti maka dapat disimpulkan bahwa terdapat model pembiasaan karakter kedisiplinan melalui kegiatan ekstrakulikuler pramuka di MI Al-Muhsin Yogyakarta melalui reward dan punisment yang diterapkan. Metode dan strategi pembelajaran dalam kegiatan ekstrakulikuler pramuka di MI Al-Muhsin Yogyakarta yaitu metodenya menggunakan prinsip dasar atau seperti belajar sambil melakukan. Model pembelajaran kegiatan ekstrakulikuler pramuka yang diterapkan di MI Al-Muhsin Yogyakarta ialah lebih ke saintifik dan langsung di alam terbuka. Adanya hubungan antara kegiatan ekstrakulikuler pramuka dengan karakter disiplin. Bukti keberhasilan kegiatan ekstrakulikuler pramuka dalam membangun karakter disiplin di MI Al-Muhsin Yogyakarta yaitu lima menit sebelum upacara atau latihan peserta didik sudah bersiap dan berkumpul dengan kondisi berbaris rapi serta mengenakan seragam pramuka lengkap, mengisi buku administrasi regu selain itu peserta didik auto tertib kalau sudah di peluit sama kakak pembina pramuka, peserta didik dengan tertib membayar iuran gugus depan, dan peserta didik suka rela membayar uang denda serta pembina pramuka juga membayar jika tidak tertib juga. Prestasi yang sudah dicapai dalam kegiatan ekstrakulikuler pramuka di MI Al-Muhsin Yogyakarta sampai saat ini adalah juara 3 Pesta Siaga Tahun 2019, Juara 2 Lomba Thilawah AKPIN Tahun 2015, dan sebagainya. Kelebihan dari kegiatan 
ekstrakulikuler pramuka di MI Al-muhsin Yogyakarta adalah kesadaran mengenakan SPL peserta didik bagus, adanya guru yang mensuport kegiatan pramuka serta dukungan dari wali murid. Sedangkan kekurangan dari kegiatan ekstrakulikuler pramuka di MI Al-Muhsin Yogyakarta adalah minimnya event lomba kepramukaan dan kuranagnya fasilitas pendukung latihan.

\section{DAFTAR PUSTAKA}

Bahasa, Tim Penyusunan Kamus Pusat Dan Pengembangan. (1989). Kamus Bahasa Indonesia. Jakarta: Balai.

Barat, Kwartir Daerah Gerakan Pramuka Jawa. (1998). Pramuka Kader Pembangunan Bangsa. Bandung: CV. Ganjar Negara.

Conny, Semiawan. (2008). Penerapan Pembelajaran Pada Anak. Jakarta: PT. Wacanan Jaya Cermelang.

Hartini, Sri. (2017). Pendidikan Karakter Disiplin Siswa Di Era Modern Sinergi Orang Tua Dan Guru Di Mts Negeri Kabupaten Klaten. Al-Asasiyya: Journal Basic Of Education, 02(01), 38-59. Diunduh dari laman web https://www.google.com/url?sa $=$ t\&source $=$ web\&rct=j\&url=http:/ journal. umpo.ac.id/index.php/al-

asasiyya/article/downloadSuppFile/882/114\&ved=2ahUKEwianJrsv9HoAh V1zzgGHSoVB1MQFjAFegQIAxAB\&usg=AOvVaw1qBu4oXETy7JoUhF STMkwT pada hari Minggu, 05 April 2020 pukul 21.50 wib.

Hurlock, Elizabeth B. (1978). Perkembangan Anak. Jakarta: Erlangga.

Ismayaningrum, Eshi. (2016). Skripsi Efektivitas Kegiatan Ekstrakurikuler Kepramukaan Dalam Menanamkan Pendidikan Karakter Di Smk. Negeri 1 Bukateja, Kecamatan Bukateja Kabupaten Purbalingga. Yogyakarta: Program Studi Manajemen Pendidikan Jurusan Administrasi Pendidikan Fakultas Ilmu Pendidikan Universitas Negeri Yogyakarta. Diunduh dari laman web http://eprints.uny.ac.id/34724/1/Eshi\%20Ismayaningrum_11101244032.pd f pada hari Senin, 05 April 2020 pukul 10.02 wib.

Juwantara, Ridho Agung. (2019). Efektivitas Ekstrakurikuler Pramuka Dalam Menanamkan Karakter Jujur Disiplin Dan Bertanggung Jawab Pada Siswa Madrasah Ibtidaiyah. Premiere Educandum: Jurnal Pendidikan Dasar dan Pembelajaran, 9(2), 160 - 171. Diunduh dari laman web http://ejournal.unipma.ac.id/index.php/PE/article/view/4994 pada hari Minggu, 05 April 2020 pukul 21.51 wib.

Laela, Haniatul. (2017). Skripsi Pendidikan Karakter Disiplin Dalam Kegiatan Ekstrakurikuler Kepramukaandi MI Modern Satu Atap Al-Az̧bary Ajibarang. Purwokerto: Program Studi Pendidikan Guru Madrasah Ibtidaiyah Fakultas Tarbiyah Dan Ilmu Keguruan Iinstitut Agama Islam Negeri (IAIN) Purwokerto. Diunduh dari laman web 
https://www.google.com/url?sa=t\&source=web\&rct=j\&url=http:// reposit ory.iainpurwokerto.ac.id/2570/1/COVER_ABSTRAK_DAFTAR\%2520ISI

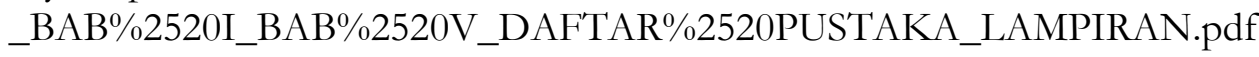
\&ved=2ahUKEwiH3jjsyNLoAhUW9XMBHbIBBmMQFjAEegQIAxAB\&u sg=AOvVaw2R7nqJlCUJ20-5NOj5hV4n\&cshid=1586141984904 pada hari Senin, 05 April 2020 pukul 09.59 wib.

Lickona, T. (2015). Character Matters: Persoalan Karakter, Bagaimana Membantu Anak Mengembangkan Penilaian Yang Baik, Integritas Dan Kebijakan Penting Lainnya. Jakarta: Bumi Aksara.

Majid, Abdul \& Dian Andayani. (2011). Pendidikan Karakter Persektif Islam. Bandung: Remaja Rosda Karya.

Meolong, Lexy J. (2005). Metode Penelitian Kualitatif. Bandung: PT. Remaja Rosda Karya.

Mulyasa, Endang. (2011). Managemen Pendidikan Karakter. Cet. Ke-1. Jakarta: Bumi Aksara.

Mustagfiroh, Hikmatul. (2020). Berita di detikNews tentang Pramuka dan Pendidikan Karakter. Diunduh dari laman web https://m.detik.com/news/kolom/d4165749/pramuka-dan-pendidikan-karakter pada hari Senin, 05 April 2020 pukul 11.52 wib.

Mustari, Mohamad. (2014). Nilai Karakter: Refleksi untuk Pendidikan. Cet. Ke-1. Jakarta: Rajawali.

Nuh, Mohammad. (2014). Salinan Peraturan Menteri Pendidikan dan Kebudayaan Republik Indonesia Nomor 63 Tabun 2014 Tentang Pendidikan Kepramukaan Sebagai Kegiatan Ekstrakulikuler Wajib Pada Pendidikan Dasar dan Pendidikan Menengah Pasal 1. Jakarta: Menteri Pendidikan dan Kebudayaan Republik Indonesia.

Nuriyatun, Puji Dwi. (2016). Skripsi Implementasi Pendidikan Karakter Disiplin Dan Tanggung Jawab Di SD Negeri 1 Bantul. Yogyakarta: Program Studi Pendidikan Guru Sekolah Dasar Jurusan Pendidikan Sekolah Dasar Fakultas Ilmu Pendidikan Universitas Negeri Yogyakarta. Diunduh dari laman web https://www.google.com/url?sa $=$ t\&source $=$ web\&rct=j\&url=https: $/ /$ core.ac .uk/download/pdf/78033157.pdf\&ved=2ahUKEwianJrsv9HoAhV1zzgGHS oVB1MQFjAEegQICRAB\&usg=AOvVaw0OeESpva1PswCnPCodKkTr pada hari Minggu, 05 April 2020 pukul 21.45 wib.

Risky. (2007). Introduction Radiance Scout. Ponorogo: Gugus Depan 15089 Gerakan Pramuka Pondok Modern Darussalam Gontor.

Suryani, Puput. (2017). Skripsi Pengaruh Kegiatan Pramuka Terhadap Kedisiplinan Siswa Kelas VIII SMP Negeri 1 Terusan Nunyai Tabun Ajaran 2016/2017. Bandar Lampung: Fakultas Keguruan Ilmu Pendidikan Universitas Lampung. Diunduh dari laman web https://docplayer.info/66718251-Pengaruhkegiatan-pramuka-terhadap-kedisiplinan-siswa-kelas-viii-smp-negeri-1-

terusan-nunyai-tahun-ajaran-2016-2017-skripsi-oleh-puput-suryani.html pada hari Minggu, 05 April 2020 pukul 22. 16 wib. 
Utari, Dian Tri. (2016). Skripsi Tesis Pendidikan Karakter Disiplin Pada Siswa Di SMP Negeri 2 Sumpiuh Kecamatan Sumpiub Kabupaten Banyumas. Purwokerto: IAIN Purwokerto. Diunduh dari laman web http://repository.iainpurwokerto.ac.id/995/ pada hari Minggu, 05 April 2020 pukul 22.14 wib.

Wadlifah, Nur. (2013). Skripsi Peran Ekstrakurikuler Pramuka Dalam Meningkatkan Kedisiplinan Siswa Di MI Hidayatul Mubtadi'in Ngudirejo Diwek Jombang. Malang: Program Studi Pendidikan Guru Madrasah Ibtidaiyah Jurusan Pendidikan Guru Madrasah Ibtidaiyah Fakultas Tarbiyah Universitas Islam Negeri Maulana Malik Ibrahim Malang. Diunduh dari laman web https: / www.google.com/url?sa $=$ t\&source $=$ web\&rct $=j \& u r l=h t t p: / /$ etheses. uinmalang.ac.id/7296/1/09140034.pdf\&ved=2ahUKEwiH3JjsyNLoAhUW9X MBHbIBBmMQFjABegQIBhAB\&usg=AOvVaw0NTOf47tZybHVAPvclD TZ4 pada hari Senin, 06 April 2020 pukul 07.44 wib.

Yusup, J. (2014). Panduan Wajib Pramuka. Jakarta: Cmedia.

Zuriah, Nurul. (2007). Pendidikan Karakter di Sekolah. Jogakarta: Laksana. 